\title{
Mengajak Generasi Z SMA 1 Muhammadiyah Malang Berinternet Secara Bijak by Hamdan Nafiatur Rosyida
}

Submission date: 20-Nov-2020 08:34AM (UTC+0700)

Submission ID: 1451718470

File name: Literasi_Digital_SMA_Muhammadiyah_1.pdf (1.53M)

Word count: 5159

Character count: 33400 


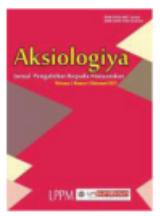

Aksiologiya: Jurnal Pengabdian Kepada Masyarakat

Vol.4, No.2, Agustus 2020 Hal 199 - 212

ISSN 2528-4967 (print) dan ISSN 2548-219X (online)

\title{
Mengajak Generasi Z SMA 1 Muhammadiyah Malang Berinternet Secara Bijak
}

\author{
Hamdan Nafiatur Rosyida ${ }^{1}$, Demeiati Nur Kusumaningrum², \\ Palupi Anggraheni ${ }^{3}$ \\ 1,2,3Program Studi Hubungan Internasional, Fakultas Ilmu Sosial dan Ilmu Politik, \\ Universitas Muhammadiyah Malang \\ Email: hamdan.nope@gmail.com¹, demeiati.nk@umm.ac.id², anggraheni.palupi@, \\ gmail.com ${ }^{3}$
}

\begin{abstract}
ABSTRAK
Hasil survei oleh Asosiasi Penyelenggara Jasa Internet Indonesia (APJII) pada tahun 2016 menunjukkan bahwa 51,8 persen dari 256,2 juta penduduk Indonesia merupakan pengguna internet dan 47,6 persennya menggunakan internet melalui gawai pribadi. Meskipun demikian, fenomena sosial mencatat tidak semua individu dapat menggunakan media sosial secara bijak. Hal itulah yang menjadi semangat kemitraan tim UMM dengan SMA 1 Muhammadiyah Malang dalam program pelatihan literasi digital. Pemahaman siswa tentang literasi digital dalam penggunaan media sosial masih minim. Siswa menguasai penggunaan media sosial popular seperi Instagram, Twitter maupun Facebook namun dampak media sosial seperti munculnya hoax, fenomena 'firehose falsehood' maupun efek domino lainnya belum terlalu mendapat perhatian. Program literasi digital dilaksanakan melalui 2 (dua) format. Pertama, Seminar dan Talkshow Literasi Digital yang terdiri dari topik perkembangan terkini media sosial, pengenalan tentang logika big data yang menentukan tajuk komposisi berita, dan pengenalan keamanan digital (cyber security). Kedua, sosialisasi berinternet secara bijak menggunakan instrumen buku saku (booklet) yang bertujuan memberikan pemahaman bagi siswa mengenai bagaimana penggunaan sosial media dan dampak positif negatif dalam berbagai perspektif studi kasus.
\end{abstract}

Kata Kunci: internet; gen z; literasi; Malang; pelatihan

\section{Invites Generation Z of Muhammadiyah Malang 1 High School to Internet Wisely}

\begin{abstract}
The results of a survey by the Indonesian Internet Service Providers Association (APJII) in 2016 showed that 51.8 percent of 256.2 million Indonesians were internet users and 47.6 percent used the internet through private devices. However, social phenomena noted that not all individuals can use social media wisely. That was the spirit of the partnership between UMM and SMA I Muhammadiyah Malang in the digital literacy training program. Students' understanding of digital literacy in the use of social media is still minimal. Students master the use of popular social media like Instagram, Twitter and Facebook but the impact of social media such as the emergence of hoaxes, the phenomenon of 'firehose falsehood' and other domino effects have not received much attention. Digital literacy program is carried out in 2 (two) formats. First, the Seminar and Digital Literacy Talkshow which consists of the latest developments in social media, the introduction of the logic of big data that determines the headline of news composition, and the introduction of digital security (cyber security). Second, internet socialization wisely uses a booklet instrument which aims
\end{abstract}


to provide students with an understanding of how social media is used and its positive and negative impacts in a variety of case study perspectives.

Keywords: internet; gen z; Malang; literacy; training

PENDAHULUAN

Semenjak dicanangkan pada tahun 2010, Revolusi Industri 4.0 dapat dikatakan menjadi sebuah era baru dalam globalisasi. Klaus Schwab - Founder and Executive Chairman of World Economic Foum menyampaikan bahwa Revolusi Industri 4.0 merupakan kelanjutan dari Revolusi Industri 3.0 yang terjadi pada tahun 1970 yang ditandai dengan komputerisasi yang mendorong otomatisasi bidang manufaktur (Schwab, 2016). Namun pada perkembangannya, era ini juga ditandai dengan dengan peningkatan teknologi berupa rekayasa intelegensia (artificial intelligent/AI) dan internet of things (IoT), wearables, robotika canggih, dan 3D sebagai sendi utama pergerakan dan konetivitas antara manusia dan mesin, yang secara fundamental mengakibatkan perubahan pada cara manusia berpikir, berinteraksi, dan beraktivitas (Ghufron, 2018; Nugraha, 2018; Prasetyo \& Tristyanti, 2018; Rohida, 2018).

Salah satu peningkatan yang terasa di Indonesia adalah sektor $I o T$ berupa meningkatnya aktivitas melalui teknologiinternetsebagai fundamental manusia dalam berkegiatan teknologi dan komunikasi. Hasil survei oleh Asosiasi Penyelenggara Jasa Internet Indonesia (APJII) pada tahun 2016 menunjukkanbahwa 51,8\%(132,7 juta) dari 256,2 juta penduduk Indonesia merupakan pengguna internet, dan $47,6 \%$ tersebut menggunakan internet melalui gawai pribadi. Data APJII 2016 juga menyebutkan pengguna internet Indonesia tertinggi didominasi oleh mahasiswa sebesar $89 \%$, yang dapat dikategorikan sebagai civitas akademika. Hal ini menunjukkan bahwa lebih dari separuh populasi masyarakat Indonesia, terutama mahasiswa, telah melek internet untuk keperluan update informasi, mencari literasi, bahkan melakukan kegiatan entertainment di media social (APJII, 2017).

Peningkatan penggunaan internet ini semakin kuat pengaruhnya di era globalisasi karena mampu menghapus batas-batas dalam penyebaran ide-ide menjadi lebih cepat, sehingga batasbatas teritori maupun ruang dan waktu menjadi semakin tidak terasa (Scholte, 2005). Selain itu, penggunaan social media dan masifnya pergerakan informasi berkaitan dengan konsep 'New Media', yang ditandai dengan kuatnya pengaruh teknologi. Internet yang mempunyai keunggulan menyatukan komunitas global menghubungkan individu dan publik yang sama-sama menjadi komunitas elektronik global yang mengaibatkan gelombang informasi mengalir tanpa ada batasan-batasan (Ravi, 2012). Meskipun demikian, tidak semua individu dapat menggunakan media sosial secara bijak. Kecenderungan penggunaan media sosial berefek pada 
polarisasi masyarakat, dapat drasakan pada momentum Pilpres 2014, yang ditandai dengan maraknya media penyebaran isu negatif dan black campaign (Testriono, 2018). Kedua Paslon berkampanye melalui media social seperti Twitter, Instagram, Facebook, dan media digital lainnya, yang kemudian ditanggapi oleh para pendukungnya untuk menyebarluaskan program kampanye tersebut melalui media komunikasi digital lainnya seperti Whatsapp, Telegram, dan Line yang menyebar melalui broadcast message di grup organisasi maupun keluarga. Pada fase ini terjadi proses komunikasi dua arah antara para pendukung Paslon seperti membuat blunder, penyebaran hoax, pembuatan fake account pendukung Paslon, hingga membuat meme satire terhadap oposisi yang justru menjadikan masyarakat terbelah menjadi dua polar berseberangan.

Pada kasus media sosial lainnya seperti Instagram, mulai banyak remaja awal hingga ibu-ibu yang mengirimkan direct message kepada artis yang mereka follow. Mereka bertindak sebagai haters yang mengirimkan makian, komentar nyinyir, bahkan ancaman kepada artis tersebut. Beberapa artis yang merasa jengah segera mengambil tindakan seperti melaporkan akun tersebut ke polisi, dan menyewa pengacara untuk melakukan proses hukum dengan jeratan pasal UU ITE. Namun akun yang melakukan hate speech tersebut seringkali mengubah nama dan profil, atau memblok akunnya, namun masih dapat terdeteksi oleh teknologi dari polisi. Hasilnya, individu pemilik akun tersebut dapat terlacak, banyak yang menghiba-hiba meminta maaf dengan alasan khilaf.

Selanjutnya, muncul permasalahan lain yang cukup meresahkan seperti beredarnya konten negatif seperti situs yang memuat konten porno, situs judi dan poker online, gim online yang memuat unsur sensualitas dan kekerasan, serta cerita fan-fiction yang mengandung unsur percintaan sesama jenis yang dimuat melalui blog atau situs sangat populer di kalangan remaja.

Banyak remaja lelaki yang kecanduan bermain gim, sedangkan remaja perempuan lebih memilih menikmati komik online seperti Webtoon maupun novel visual seperti Wattpadd yang beberapa kontennya terlalu vulgar dan membawa isu-isu LGBT. Kebanyakan situs seperti ini tidak dapat dibuka semenjak Internet Sehat (Insan) yang dicetuskan Kominfo pada tahun 2012, namun eksekusinya baru dilakukan pada tahun 2016 dengan menggunakan karakter remaja perempuan bernama Ipo yang merupakan singkatan dari 'Internet Positif'. Meskipun demikian, program Insan tetap tidak dapat diredam semenjak kehadiran aplikasi seperti $V P N$ yang dapat diunduh pada Playstore maupun App Store.

Permasalahan yang paling vital adalah lahirnya Youtuber dan Selebgram, maupun public figure lainnya yang memposting kegiatan yang terkadang kurang bermanfaat pada channel mereka. Contohnya adalah channel Queen of Youtube 
Ria Ricis yang 'menjual' squishy menjadi popular di kalangan anakanak, sehingga angka pembelian squishy meningkat di kalangan remaja, bahkan ia sempat dihujat oleh komunitas pecinta lingkungan karena videonya yang membuang squishy ke laut, namun justru dibela oleh fans Ricis yang masih remaja. Contoh lainnya adalah King of Youtube Atta Halilintar yang viral dengan kontennya yang menggrebek rumah artis sempat dituding plagiat konten isi youtuber Putu Reza, namun justru ia dibela fans AHHA channel. Munculnya aplikasi karaoke Smule yang menyebabkan perubahan perilaku dan hilangnya privasi, serta aplikasi TikTok yang sempat viral dengan Kiki Challenge menjadi sangat populer, para remaja banyak yang mengupload video TikTok mereka ke media sosial, memunculkan predator dan menimbulkan kasus cyber crime, serta kecelakaan. Serta isu terpanas pada akhir tahun 2018 adalah channel komika jebolan standup comedy Coki Pardede dan Tretan Muslim yang menyinggung SARA dengan videonya yang dihujat karena dituding menista agama berisi konten video memasak babi campur kurma menjadi trending video di Youtube, menimbulkan banyak remaja yang mulai mengikuti jejak mereka dengan melakukan pencelaan terhadap agama.

Serta yang tidak mungkin dilupakan adalah kejadian plagiarisme dalam penulisan karya ilmiah oleh seorang profesor di salah satu universitas terkenal pada beberapa tahun lalu, yang membuat Profesor tersebut dicabut gelar akademiknya. Hal ini menjadi cambuk pada civitas akademikalainnyauntuklebihwaspada akan segala bentuk plagiarisme, serta meningkatkan kesadaran mengenai etika penulisan ilmiah. Untuk mencegah hal ini terulang kembali, maka perlu pelatihan literasi digital sejak dini.

Kejadian-kejadian di atas menunjukkan bahwa masyarakat Indonesia, terutama remaja, masih tidak dapat menggunakan internet dengan bijaksana dikarenkan minimnya pengetahuan tentang literasi digital, serta tidak mempunyai etika yang baik di media sosial. Kata literasi digital pertama kali dicetuskan oleh Paul Gilster dalam bukunya berjudul Digital Literacy pada tahun 1997, yang bermakna kemampuan untuk memahami dan menggunakan informasi dalam berbagai bentuk dari berbagai sumber luas yang diakses melalui computer. Berbeda dengan Bawden (2001) yang mengemukakan pemahaman baru bahwa literasi digital berakar dari literasi komputer yang booming pada tahun 1980-an dan literasi informasi yang menyebar pada 1990-an ketika informasi sudah mudah disusun melalui jejaring. Dengan demikian, literasi digital dapat dipahami sebagai keterampilan teknis mengakses, merangkai, memahami, dan menyebarluaskan informasi (Tim GLN, 2017).

Ada delapan aspek dalam mengembangkan literasi digital menurut Douglas A.J. Belshaw, yaitu (1) Kultural, atau pemahaman ragam konteks pengguna dunia digital, (2) 
Kognitif, yaitu daya pikir menilai konten, (3) Konstruktif, reka cipta sesuatu yang actual, (4) Komunikatif, memahami kinerja jejaring dan komunikasi di dunia digital, (5) Kepercayaan diri, (6) Kreatif, (7) Kritis dalam menyikapi konten, dan (8) Bertanggung jawab secara sosial.

Perkembangan media menjadi sebuah peluang yang baik bagi pengguna yang dapat menggunakan internet dengan bijak. Tujuan dari menjadi literasi digital yang baik seharusnya dapat memproses berbagai informasi lalu memahaminya dan diolah kembaliuntukdikomunikasikan ulang kepada orang lain. Tidak terbatas pada proses memahami informasi saja, tetapi juga melatih proses berpikir kritis terhadap dampak positif dan negative dari hasil informasi tersebut, serta dampaknya jika menggunakan teknologi dalam keseharian secara kontinyu. Pada fase ini, individu dipacu untuk beralih dari konsumen pasif menjadi konsumen aktif baik secara individu maupun komunitas, contohnya adalah penyampaian opini dan gagasan, penambahan informasi, maupun reinterpretasi. Jika remaja kurang menguasai literasi digital, maka tidak mustahil jika akan tersisih dari persaingan memperoleh pekerjaan, partisipasi demokrasi, dan interaksi sosial.

Remaja saat ini atau yang sering disebut generasi millennial dan generasi $\mathrm{Z}$ merupakan generasi yang akrab dengan teknologi (Kusumaningrum, 2018). Hasugian dalam Riana (2011) membagi pembabakan generasi di Indonesia menjadi 6 kategori, yaitu (1) The Greatest Generation yang lahir pada masa Perang Dunia I (1901-1924), (2) Silent Generationyang lahirpadatahun 1925-1942 di tengah masa Perang Asia Pasifik yang mencekam, (3) Baby Boomers yang lahir pada 19431960 merupakan program pemerintah untuk meningkatkan jumlah populasi penduduk yang meninggal karena perang, (4) Generasi X yang lahir pada 1961-1981, dimana Indonesia tengah membangun sistem ekonomi yang lebih baik, (5) Generasi Millenial yang lahir pada tahun 1982-2002, dimana generasi ini mulai mengalami kehidupan ekonomi yang lebih baik, dan (6) Generasi $Z$ yang biasa disebut generasi digital natives atau internet generation yang lahir pasca 1994 hingga sekarang, yang mana generasi ini mendapatkan sentuhan teknologi semenjak bayi karena orangtua mereka juga terbiasa menggunakan gawai (Mardina, 2017).

Karakteristik dari generasi internet ini adalah akrab dan menikmati segala bentuk aktifitas yang berhubungan dengan komputer dan internet, mempunyai keinginan untuk selalu terhubung dengan internet setiap saat, aktif menciptakan konten-konten untuk dibagikan kepada orang lain sebagai influencer, serta sangat aktif dalam media social (Kusumaningrum, 2018; Prensky, 2001, p. 9). Ghaith (2010) dalam Riana juga mengungkapkan bahwa karakter generasi ini sangat menikmati berbagai aktifitas online, seperti bermain gim hingga menciptakan pertemanan, mengupdate info, berkolaborasi dalam jejaring, dan menyukai informasi berbasis hypertext. Mereka juga cenderung memperoleh informasi secara instan, 
cenderung multitasking, menikmati informasi visual yang dinamis maupun gambar yang interaktif, serta adanya kecenderungan pengakuan atas pendapat mereka.

Penggunaan teknologi digital ini berdampak pada gaya belajar yang cenderung mencari informasi secara cepat dan singkat, sehingga terciptalah generasi cepat dan instan, tanpa mau membaca informasi secara lengkap dan menyeluruh (Lankshear \& Knobel, 2006). Aktifitas browsing menjadi lebih dinamis karena berpatokan pada konten digital yang setiap hari berganti topik, berbeda dengan pengalaman membaca buku yang bersifat statis, dimana kebaruan konten buku jauh lebih lambat dibandingkan dengan situs, sehingga pembaca tidak akan kehilangan makna buku tersebut meskipun sudah mengalami revisi. Hal inilah yang membuat generasi millennial kurang bijak dalam memandang sesuatu, dan mudah terjerat dalam trending topic media social yang mudah berubahubah. Jika berkelanjutan, maka dapat mengganggu proses belajar remaja, bahkan mengalami gangguan psikologis seperti cyberbullying, hate speech, penyebaran hoax, dan lain sebagainya.

Sisi positifnya, remaja yang menggunakan internet secara positif mampu menangkap peluang kreatif yang ada di sekitarnya, seperti kemunculan social media influencer hingga peluang entrepreneurship seperti endorse barang. Mereka yang berpikir positif, juga tidak mudah termakan isu provokatif, menjadi korban informasi hoax, maupun mudah menjadi korban penipuan digital. Dengan demikian, dapat menciptakan ketentraman dan kedamaian social di masyarakat. Oleh karena itu, perlu diadakan pelatihan literasi digital pada remaja agar mereka dapat menggunakan internet secara bijak.

Berdasarkan analisis situasi di atas, dan hasil wawancara beberapa tenaga pendidik di SMA 1 Muhammadiyah Malang, dapat diidentifikasi permasalahan mitra yang berhubungan dengan program pengabdian ini yakni sebagai berikut; (1) Minimnya pemahaman siswa dan siswi tentang literasi digital dalam penggunaan media sosial. Perkembangan media sosial mayoritas hanya dipahami tentang bagaimana penggunaanmediasosialpopularseperi Instagram, Twitter maupun Facebook. Pemahaman mengenai dampak media social seperti munculnya hoax, fenomena firehose falsehood maupun efek domino lainnya belum terlalu mendapat perhatian dari siswa siswi. (2) Keterbatasan mitra dan minimnya medium berdiskusi kritis dengan siswa-siswi khususnya di fase remaja akhir-usia dewasa awal, yang menjadi kelompokumurutamapengguna sosial media. Kondisi ini menyebabkann media sosial seringkali dipahami secara hitam putih. Kurangnya pemahaman mengenai kontribusi positif sekaligus dampak dari sosial media menghasilkan beberapa permasalahan yang jamak dihadapi siswa seperti bullying, hatespeech, hedonisme, konsumerisme, copying behaviour dan lain lain.

Berdasarkan permasalahan di 
atas maka terdapat beberapa solusi yang ditawarkan kepada mitra dalam kegiatan ini diantaranya: (1) Mitra diharapkan memiliki kemampuan literasi digital yang baik, dan mampu beradaptasi sekaligus bersikap kritis atas melimpahnya informasi, khususnya pada fenomena masifnya penggunaan media social, (2) Mitra dapat menjadi konsumen yang cerdas dalam memfilter informasi digital yang berpotensi menimbulkan efek samping seperti cyber bullying, maupun dampak negatif lainnya, serta dapat memilih konten digital yang memberi dampak positif dan bermanfaat sesuai dengan batasan usia. (3) Mitramampumemahamitantangan sekaligus dampak dari perkembangan social media, khususnya bagi remaja millenial. Atensi mitra yang tinggi atas penggunaan sosial media dapat dioptimalisasi untuk tujuan positif, dan (4) Mitra melibatkan dan meningkatkan pemberdayaan untuk siswa dan siswi, terutama dalam isuisu cyberbulling, hatespeech dan dampak psikologis lainnya terkait penggunaan media sosial bagi siswasiswi.

\section{METODE}

Tim melaksanakan kegiatan pengabdian masyarakat di SMA 1 Muhammadiyah Malang dalam 2 (dua) format. Pertama, Seminar dan Talkshow Literasi Digital dengan sub materi yang akan disampaikan terdiri dari perkembangan terkini media social, pengenalan sekilas tentang logika big data yang menentukan tajuk komposisi berita, dan pengenalan keamanan digital (cyber security). Kedua, Sosialisasi Literasi Digital. Sosialisasi bertujuan untuk memberikan pemahaman bagi siswa mengenai bagaimana siswa menyikapi penggunaan sosial media. Adapun kegiatan sosialisasi ini dibagi menjadi dua tahap.

(1) Tahap identifikasi. Hal ini meliputi pengenalan bagaimana melimpahnya arus informasi di era social media memiliki beberapa efek sampingan positif maupun negatif. Lebih lanjut, peserta juga diperkenalkan mengenai bagaimana social media dapat merubah preferensi perilaku maupun menyebabkan beberapa gangguan psikologis seperti cyber bullying ataupun adiksi. (2) Tahap interaktif. Tahapan ini merujuk pada pemberian ruang bagi peserta (siswa siswi seminar) untuk melihat langsung contoh contoh penggunaan social media yang bijak dan sekaligus pada sesi tanya jawab mendorong partisipasi peserta untuk menceritakan tentang pengalaman yang dihadapi dalam penggunaan social media, permasalahan dan solusi yang ditempuh.

\section{HASIL DAN PEMBAHASAN}

Secara umum, kegiatan Pelatihan Literasi Digital yang dijalankan oleh Tim terdiri dari dua sesi pelatihan yang dilaksanakan pada Senin 15 Juli 2019. Desain awal pelatihan ini diperuntukkan untuk siswa-siswi SMA 1 Muhammadiyah secara umum, tidak secara khusus mengkhususkan pada kelas tertentu. Namun, atas permintaan mitra, pelatihan yang 
sedianya didesain untuk audiens kecil sesuai kapasitas kelas, didesain ulang untuk disajikan pada pembukaan masa orientasi siswa baru.

Sesi pertama pelatihan menitikberatkan pada pengenalan awal mengenai perkembangan teknologi dan informasi, dan efek positif serta negatinya. Selanjutnya pada sesi kedua, materi pelatihan difokuskan pada bagaimana penggunaan sosial media yang bijak, khususnya menyasar pada khususnya penggunaannya pada siswa-siswi usia sekolah. Masing-masing sesi mendapatkan alokasi waktu sekitar 20 menit, yang kemudian diiringi dengan sesi tanya jawab terkait materi sosialisasi yang diberikan.

\section{Perkembangan Teknologi}

Informasi: Konsekuensi

Interkonektivitas dan

Dampaknya bagi Siswa

Sesi pertama pelatihan dibuka dengan pemamparan gambaran umum tentang perkembangan internet dan dnia digital yang juga ditandai dengan semakin masifnya penggunaan media sosial. Pesatnya potensi pengguna internet di Indonesia, harus ditandaidengan kemampuan berfikir kritis yang pada akhirnya menumbuhkan kemampuan menyaring informasi yang baik ditengah "gempuran" informasi yang serba instan.

Perkembangan dunia digital, khususnya pesatnya distribusi informasi melahirkan beberapa fenomena baru yang perlu mendapat perhatian khusus dari masyarakat, terutama bagi kalangan pelajar tingkat menengah atas yang mulai memiliki rasa keingintahuan yang besar. Penggunaan social media dan layanan pesan instan seperti WhatsApp, Line, Kakao dll selain menawarkan kemudahan berkomunikasi, juga memiliki efek samping yang cukup berbahaya apabila tidak disikapi dengan bijak.

Pemberian materi diawali dengan pemaparan jumlah pengguna internet di Indonesia yang terus mengalamipeningkatan dari tahun ke tahun, berdasarkan survey yang diselenggarakan oleh APJII (Asosiasi Penyelenggara Jasa Internet Indonesia) pada tahun 2016. Lebih lanjut survey ini memetakan komposisi pengguna internet yang didominasi oleh masyarakat usia produktif (25-34 tahun dan 3544 tahun), namun seiring dengan bonus demografi Indonesia jika tidak ditanamkan pemahaman penggunaan internet yang bijak, potensi penyalahgunaan internet oleh pengguna di bawah umur akan semakin besar dari waktu ke waktu (APJII, 2017).

$$
\text { Setelah pengenalan }
$$
singkat tentang komposisi penggunaan internet, peserta juga mendapatkan informasi mengenai perkembangan mutakhir dari pesatnya sektor digital. Tidak dapat dipungkiri, aktivitas keseharian manusia mengalami kemudahan dengan hadirnya 
layanan mesin pencari (search engine) daring, namun kemudahan ini juga memiliki beberapa dampak negatif seperti: mudah bocornya data pribadi pengguna hingga maraknya persebaran berita bohong (hoax). Sub tema mengenai mudah tersebarnya data pribadi (username, password dll) menjadi perhatian tersendiri bagi peserta pelatihan karena sering munculnyapenawaran-penawaran menarik pada saat berselancar di dunia maya. Dalam sesi tanya jawab, terungkap bahwa mayoritas peserta tidak menyadari bahwa persebaran data online mereka terjadi saat mengunduh applikasi berbasis Android maupun iOS. Hal ini dapat diminimalisir dengan menghindari mengunduh aplikasi yang scera spesifik menyebutkan meminta persetujuan akan mengakses data pribadi seperti username, password, lokasi hingga daftar kontak yang tertera di gawai.

Kesadaran tentang perlindungan data pribadi ini menjadi penting untuk disampaikan dalam sesi pelatihan dengan audiens pelajar, mengingat pemerintahsendiribelummemiliki regulasi yang komprehensif terkait perlindungan data pribadi secara daring. Hingga saat ini, RUU Perlindungan Data Pribadi masih dalam tahap pembahasan antara pemerintah dan legislatif dan ditargetkan selesai pada Oktober 2019 (Pratomo, 2019). Padahal kejahatan siber dan aspek sosial lain seperti perundungan siber, dan pemerasan cukup potensial dialami oleh pelajar. Sejauh ini payung hukum yang tersedia adalah Peraturan Menteri Komunikasi dan Informasi (Permen) No 20 Tahun 2016 tentang Perlindungan Data Pribadi (PDP) yang merupakan turunan dari Peraturan Pemerintah (PP) No 82/2012 tentang Penyelenggaraan Sistem dan Transaksi Elektronik (PSTE) yang diundangkan dan berlaku sejak 15 Oktober 2012 (Yovita, 2016). Lebih lanjut, dari press release Kominfo tersebut, Sekretaris Direktorat Jenderal Informasi dan Komunikasi Publik Kementerian Komunikasi dan Informatika, Drs. Ismail Cawidu, MM, mengungkapkan pemerintah memang telah memiliki beberapa peraturan perundang-undangan terkait perlindungan data pribadi, seperti UU No.36/1999 tentang telekomunikasi, UU No.23/2006 tentang administrasi kependudukan, UU No11/2008 tentang ITE. Namun, jangkauan pengaturannya masih belum komprehensif dan seringkali bersifat sektoral.

Berangkat dari kesadaran tentang perlindungan data pribadi, materi kemudian dilanjutkan pada pemetaan lanjutan pengenai masifnya perkembangan sektor digital. Kemudahan penggunaan mesin pencari daring komunikasi via media sosial dan layanan pesan instan juga perlu disikapi bijak oleh peserta. Kondisi ini 
terkait dengan perkembangan tren big data, yang didefinisikan oleh Snijders et al., (2012) sebagai "a more formal definition of the term suggests that it is data "with sizes beyond the ability of commonly used software tools to capture, curate, manage, and process the data within a tolerable elapsed time"(Narendra, 2018).

Dengan munculnya big data, analisis data online yang tersebar di dunia maya, data pribadi pengguna internet dapat digunakan oleh siapa saja, baik untuk tujuan komersial dan riset mapun hal lainnya. Pemateri memberikan contoh sederhana penetrasi system Big data pada audiens, yakni preferensi pop ads pada aplikasi akan menyesuaikan history / jejak pola pencarian di mesin pencari. Pada skala yang lebih besar, efek dari penghimpunan data secara masif melalui sistem Big Data dapat dilihat pada kasus yang melibatkan perusahaan riset Cambridge Analytica (CA) yang berkaitan erat dengan pemilihan Presiden Amerika Serikat tahun 2016. Perusahaan data analis ini terindikasi kuat telah mengambil data pribadi 50.000 pengguna Facebook secara illegal dan tanpa izin dari penggunanya. Menurut informasi yang dikutip dari liputan Tirto, data yang diambil adalah semua data mentah terkait demografi, kontak pribadi dan pemetaan kecenderungan politik masyarakat (Faisal, 2018).

Data pengguna facebook dihimpun tanpa izin pengguna secara langsung, melainkan dari keikutsertaan pengguna dalam aplikasi kuis maupun aplikasi dari Facebook yang mengizinkan mereka mengakses aktivitas pengguna, jejaring pertemanan dan profil yang secara legal memang diperbolehkan oleh Facebook saat itu. Selanjutnya kumpulan data dan preferensi pribadi yang diperoleh tersebut, digunakanuntuk kepentinganklien yang rata-rata bertarung dalam pemilihan politik dan jabatan publik dengan cara mempengaruhi preferensi pilihan politik (baik dengan cara legal laupun illegal) dari pemilih di beberapa negara seperti Amerika Serikat, Kenya, Kolombia, India, serta St Kitts \& Nevis melalui suggestion/ saransaran pemberitaan hoaks yang mendeskriditkan lawan politik (Rosenberg, Confessore, \& Cadwallard, 2018).

Vitalnya pemahaman generasi muda atas perkembangan literasidigitalmenjadipoinpenutup dari pemberian materi di sesi ini. Lebih lanjut, kasus pencurian data pribadi maupun persebaran hoax tidak akan menimbulkan dampak masif apablia masyarakat tanggap dan memiliki kemampuan memverifikasi kebenaran berita yang tersebar dengan baik. Sebagai tambahan, peserta juga mendapatkan informasi baru teknik propaganda yang 
mulai marak digunakan melalui penyebaran berita bohong (hoaks) yang dapat tersebar cepat melalui layanan pesan instan, yakni semburan kebencian (Firehouse of Falsehood). Perserbaran hoaks dengan frekuensi tinggi dan disebarkanakansulitdiminimalisir dan dapat menimbulkan dampak serius seperti kerusuhan massa maupun kepanikan apabila masyarakat tidak memiliki kemampuan verifikasi kesahihan sumber berita secara mumpuni.

\section{Penggunaan Media Sosial dengan Bijak}

Pada sesi selanjutnya, materi sosialisasi lebih menekankan pada bagaimana penggunaan sosial media yang bijak. Audiens diajak untuk merefleksikan kembali apakah aktivitas enggunaan sosial media yang mereka jalankan sehari-hari memang bermanfaat dan sesai dengan usia pengguna yang masih dalam usia sekolah.

$$
\text { Pemateri menjelaskan }
$$$$
\text { tentang kriteria pengguna }
$$
media social terbagi tiga, yaitu narcissm, shyness, dan loneliness, berdasarkan teori Ryan $\mathrm{T}$ \& Xenos (Silvana \& Darmawan, 2018). Narcissm diketagorikan bagi pengguna media sosial yang sering mengunggah (posting) halhal yang semestinya tidak perlu diunggah (superficial behavior), dan media sosial digunakan sebagai menawarkan diri sendiri (self-promoting); Shyness adalah tipe pengguna yang memiliki kecemasan sosial yang tinggi, sehingga sering mengunggah postingan dalam jumlah yang banyak untuk mengatasi kecemasan diri pengguna; dan terakhir adalah Loneliness yang mengalami kesepian, penuh rasa cemas dan kekhawatiran berlebih, sehingga cenderung mendapat kenyaman berlebih jika melakukan interaksi secara daring (online) sesama manusia.

Melalui penyajian materi, audiens juga disajikan beberapa identifikasi permasalahan utama dalam penggunaan internet, di antaranya: penggunaan berlebih, penyebaran berita hoaks, penelusuran konten dewasa, konten tontonan yang tidak berkualitas ataupun kecenderungan menjadi korban maupun pelaku perundungan daring (cyberbullying).

Namun di sisi lain, penggunaan media social yang bijak juga dapat memberikan dampak positif bagi siswa. Tren penggunaan social media oleh remaja yang terdiri dari : penyedia content, pencarian materi dan tugas sekolah / browsing serta meningkatnya kemunculnya influencer(selebgram,vlogger,dll) . Pemateri memberikan beberapa klasifikasi tontonan positif yang dapat membantu oleh audiens, yakni: konten edukatif, konten inspiratif, konten informative dan konten hiburan.

Beberapa temuan yang diperoleh oleh Tim Pengabdian 
di antaranya; Pertama, Peserta umumnya menggunakan sosial media dan layanan pesan instan memiliki tujuan untuk mempermudah komunikasi sekaligus menjadi sarana eksistensi diri. Beberapa peserta didik mengakui mengikuti sosok berpengaruh (influencer) di Instagram. Siswi perempuan mengikuti beberapa influencer seperti Ria Ricis, maupun beauty vlogger seperti Suhay Salim, Rachel Goddard, maupun Tasya Farasya. Sementara siswa laki-laki umumnya menggunakan social media sebagai platform awal dalam bermain gim-gim berbasis daring, seperti mobile legend, $G T A$, dan lain sebagainya.

Kedua, Beberapa peserta pelatihan, pada sesi tanya jawab mengungkapkan bahwa secara tidak sengaja mereka juga sering mengakses konten-konten yang tidak sesuai umur dalam bentuk pop up ads (iklan dalam wujud peramban yang muncul secara otomatis tanpa permisi, tanpa merasa telah membukanya). Ketiga, peserta pelatihan juga mengungkapkan adanya mengalami kebingungan, dalam menyaring lalu lintas berita-berita yang mereka konsumsi, khususnya menjelang masa Pemilihan Umum April 2019 (baik pemilihan di level legislatif maupun pemilihan pasangan calon Presiden-Wakil Presiden).

\section{SIMPULAN}

Pelatihan literasi digital dan sosialisasi berinternet secara bijak mendapat apresiasi positif. Atas usulan mitra, pelatihan ini direncanakan akan dilaksanakan sekali lagi, setelah masa pengenalan peserta didik baru usai. Mitra juga memberikan masukan untuk pelatihan yang akan datang, diharapkan pelatihan juga berfokus pada peningkatan kesadaran peserta didik dalam penggunaan internet, khususnya pada kemampuan untuk menerapkannya pada pembuatan tugas dalam kegiatan belajar mengajar maupun penggunaannya dalam penulisan karya ilmiah. Desain pelatihan sedianya akan diperkecil, dan fokus pada kelas-kelas kecil untuk membentuk kelompok diskusi kecil, dengan sasaran peserta kelas $\mathrm{XI}$, termasuk pengurus OSIS dan KIR (Karya Ilmiah Remaja).

\section{DAFTAR PUSTAKA}

APJII. (2017). Pemetrasi \& Perilaku Pengguna Internet Indonesia. Retrieved from https:// web.kominfo.go.id/sites/ default/files/Laporan Survei APJII_2017_v1.3.pdf

Faisal, M. ${ }^{-}(201 \overline{8})$. Heboh Kasus Pencurian Data Cambridge Analytica. Retrieved December 9, 2019, from https://tirto.id/ heboh-kasus-pencurian-datacambridge-analytica-cGuw

Ghufron, M. A. (2018). Revolusi Industri 4.0: Tantangan, Peluang dan Solusi Bagi Dunia Pendidikan (August 2, 2018). Seminar Nasional dan Diskusi Panel Multidisiplin Hasil Penelitian \& Pengabdian kepada Masyarakat. Jakarta: Universitas PGRI Indraprasta 
(Unindra). Retrieved from http://www.proceeding.unindra. ac.id/index.php/dispanas2018/ article/viewFile/73/45

Kusumaningrum, D. N. (2018). Millenials:TransnationalCitizen - Dealing with Constructivist and Cosmopolitan Perspectives. In Proceedings of the Annual Conference on Social Sciences and Humanities - Volume 1: ANCOSH. April 24-24, 2018 (Vol 1, pp. 18-21). Malang: SciTePress. Retrieved from https://www.scitepress. org/Publications Detail. aspx?ID $=$ pkVdtaAr83I $=\& \mathrm{t}=1$

Lankshear, C., \& Knobel, M. (2006). Digital Literacy and Digital Literacies: Policy, Pedagogy and Research Considerations for Education. Digital Kompetanse, 1(1), 12-24. Retrieved from http://everydayliteracies.net/ files/digital_kompetence_2006. pdf

Mardina, R. (2017). Literasi Digital bagi Generasi Digital Natives. Universitas Kristen Krida Wacana. Retrieved from https://www.researchgate.net/ publication $/ 326972240 \% 0 \mathrm{D}$

Narendra, A. P. (2018). Big Data, Data Analyst, and Improving the Competence ofLibrarian.Record and Library Journal, 1(2), 83. https://doi.org/10.20473/rlj.vli2.2015.83-93

Nugraha, D. (2018). Transformasi Sistem Revolusi Industri 4.0. In Workshop Technopreneurship Road to TBIC 2019. Kemenristekdikti. Retrieved from https://puspiptek. ristekdikti.go.id/wp-content/ uploads/2018/10/revolusiindustri-4.0_PIF-2018_2018-1. pdf

Prasetyo, B., \& Tristyanti, U. (2018). Revolusi Industri 4.0 dan Tantangan Perubahan

$\begin{array}{lr}\text { Sosial. In Prosiding } \\ \text { SEMATEKSOS } 3 & \text { "Strategi } \\ \text { Pembangunan r Nasional } & \text { NenghadapiRevolusiIndustri } \\ \text { Mengher } & \text { 4.0"(pp.22-27). IPTEK Journal } \\ \text { of Proceedings Series. https:// } \\ \text { doi.org/10.12962/j23546026. } \\ \text { y2018i5.4417 }\end{array}$

Pratomo, Y. (2019). UU Perlindungan Data Pribadi Ditargetkan Rampung sebelum Oktober. Kompas.Com. Retrieved from https://tekno.kompas.com/ $\mathrm{read} / 2019 / 06 / 18 / 14030057 /$ uu-perlindungan-data-pribadiditargetkan-rampung-sebelumoktober $\% 0 \mathrm{~A}$

Prensky, M. (2001). Digital Natives, Digital Immigrant. On the Horizon, 9(5), 1-6. Retrieved from https://www.marcprensky. com/writing/Prensky - Digital Natives, Digital Immigrants Partl.pdf

Ravi, B. K. (2012). New Media, Culture and Society. Academic Research International, 2(2), 479-494. Retrieved from www. savap.org.pkwww.journals. savap.org.pk

Rohida, L. (2018). Pengaruh Era Revolusi Industri 4.0 terhadap Kompetensi Sumber Daya Manusia. Jurnal Manajemen Dan Bisnis Indonesia, 6(1), 114 136. https://doi.org/10.31843/ jmbi.v6il.187

Rosenberg, M., Confessore, N., \& Cadwallard, C. (2018). How Trump Consultants Exploited the Facebook Data of Millions. The New York Times. Retrieved from https://www.nytimes. com/2018/03/17/us/politics/ cambridge-analytica-trumpcampaign.html

Scholte, J. A. (2005). Globalization: A Critical Introduction (Second). London: Red Globe Press. Retrieved from https:// www.academia.edu/37950875/ 
Globalization A Critical Introduction_by_Jan_Aart_Scholte

Schwab, K. (2016). The Fourth Industrial Revolution. New York: Crown Bussiness.

Silvana, H., \& Darmawan, C. (2018). Pendidikan Literasi Digital di Kalangan Usia Muda di Kota Bandung. PEDAGOGIA, 16(2), 146. https://doi.org/10.17509/ pdgia.v16i2.11327

Testriono, F. (2018). Polarisasi politik tak melulu buruk-asalkan dua syarat terpenuhi. The Conversation. Retrieved from https://theconversation.com/ polarisasi-politik-tak-meluluburuk-asalkan-dua-syaratterpenuhi-92279

Tim GLN. (2017). Materi Pendukung Literasi Digital. Jakarta: Kemendikbud. Retrieved from https://gln.kemdikbud. go.id/glnsite/wp-content/ uploads $/ 2017 / 10 /$ literasi DIGITAL.pdf

Yovita. (2016). Indonesia Sudah Miliki Aturan Soal Perlindungan Data Pribadi. Retrieved December 9, 2019, from https://kominfo. go.id/content/detail/8621/ indonesia-sudah-milikiaturan-soal-perlindungan-datapribadi/0/sorotan_media 
Mengajak Generasi Z SMA 1 Muhammadiyah Malang Berinternet Secara Bijak

ORIGINALITY REPORT

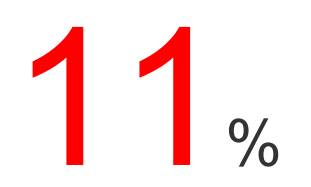

SIMILARITY INDEX
$10 \%$

INTERNET SOURCES
$3 \%$

PUBLICATIONS
$6 \%$

STUDENT PAPERS

PRIMARY SOURCES

1 pelajarancg.blogspot.com

Internet Source

2 es.scribd.com

Internet Source

3 kominfo.go.id

Internet Source

4 digilib.uin-suka.ac.id Internet Source

5 www.kominfo.go.id Internet Source

6 Submitted to Academic Library Consortium Student Paper

7 ejurnal.mercubuana-yogya.ac.id Internet Source

8 text-id.123dok.com Internet Source 
10 Submitted to Universitas Indonesia Student Paper

11 pt.scribd.com

Internet Source

12 jurnal.pnj.ac.id

16 medium.com

17 Records Management Journal, Volume 24,

Issue 2 (2014-09-16)

Publication

18 mr-alim.blogspot.com

jurnal.upnyk.ac.id 


\section{Submitted to Dewan Perwakilan Rakyat}

27 www.zawya.com

Internet Source

28 www.i-conferences.org 
33 id.123dok.com

Internet Source

34 tailieu.vn

Internet Source

35 repository.isi-ska.ac.id

36 Submitted to University of Western Australia Student Paper

37 ejournal.iahntp.ac.id

38 moam.info

Internet Source

39 WwW.cogentoa.com

40 sandyagilang.blogspot.com

41 Submitted to Los Angeles City College 
Exclude quotes

On

Exclude matches

Off

Exclude bibliography

On 


\section{Mengajak Generasi Z SMA 1 Muhammadiyah Malang Berinternet Secara Bijak}

GRADEMARK REPORT

FINAL GRADE

10

PAGE 1

PAGE 2

PAGE 3

PAGE 4

PAGE 5

PAGE 6

PAGE 7

PAGE 8

PAGE 9

PAGE 10

PAGE 11

PAGE 12

PAGE 13

PAGE 14
GENERAL COMMENTS

Instructor 